\title{
A Letter from Copernicus the Cat to Chris Marker
}

\section{Lauren Bliss}

Part 1: On seeing the future lost

Chris Marker (29 July 1921 - 29 July 2012) figures his identity like his filmmaking, under the sign of erasure. As a young man, he changed his name from Christian Hippolyte François Georges Bouche-Villeneuve to Chris Marker (apparently because Chris Marker fitted on his passport); ${ }^{1}$ less than twelve photographs of him exist, he has only ever given a small number of interviews, ${ }^{2}$ and when asked for a photograph he generally responded with a picture of a cat. His films, made from 1952 until his death in 2012, attend to the paradox of the lost memory. These losses are figured in the form of the future that could have been, as a vanishing nostalgia or a nostalgia for the future which did not come.

La Jetee (1962) is the premiere example of Marker's artistic rendering of this paradox, insofar as it is a film set in the post-apocalyptic future about a man tortured by a group of scientists, who experiment on him to see if time travel is possible in order to try and rescue the present. The scientists send him into the past, where he sees a man being shot on the jetty at Orly airport, a vision that later turns out to be the impossible memory of the man's own death-one that occurred at the hands of the scientists to prevent their prisoner from exposing the secret of time travel. Although Marker is often linked, in his artistic rendering of time, war and social alienation, to the other left bank filmmakers of Paris such as Alain Resnais (Night and Fog, 1955; Hiroshima mon amour, 1959; Last Year at Marienbad, 1961) and Agnes Varda (Cleo from 5 to 7,1961$)$, it is well known that he belongs to the wider 
cinephilic tradition that sought to film the revolution, or revolutionise society through film, which is perhaps the same thing. As the uprisings and social revolutions of the late $1960 \mathrm{~s}$ took place, filmmakers all over the world created a swathe of films under the influence of semiotic film theory. Itself influenced by Freud and Marx, semiotic film theory is guided by the idea that film has direct, if unconscious, impact on the psyche and imagination. Marker, with a host of other filmmakers including Jean-Luc Godard and Jean Pierre Gorin of the Dziga Vertov Group, Laura Mulvey, Peter Wollen and Masao Adachi, inherited the Soviet tradition of dialectical montage and sought to cinematise revolution, to wake up the eye and mind to capitalist and global oppression through the filmic medium.

A Grin Without a Cat-made in 1977-is in fact a eulogy to the failure of the 1968 uprisings of Paris, and for the increasing understanding that cinema would never achieve this dream of revolution. ${ }^{3}$ What takes the placecard of this invisibility, this nostalgia for that which never came, is the image of the cat. The cat is at once Marker's own personal signature and an odd figure of political defiance. For cats, as the film tells us through the words of Louis Althusser, are never on the side of power. A Grin Without a Cat of course takes its name from the Cheshire cat in Alice in Wonderland, whose grin remains after his body disappears. This disappearing body is figured through Marker's complex and carefully composed montage as it juxtaposes shots of the powerful to the powerless, including images of the May '68 riots in Paris, with the uprisings in Latin America, the Prague Spring and resistance to Vietnam War. These are placed in a visual collage, or constellation, that moves from images of the powerful-the soldiers, and the government forces, discussing techniques of torture-to students and workers engaged in mass protest and voicing their demands. This dialectical montage invokes Marker's indebtedness to the Soviet filmmakers Sergei Eisenstein and Dziga Vertov insofar as it aims to create new meaning by colliding independent shots together. However, A Grin Without a Cat moves away from the idealism, and thus the manipulative streak, that marks Soviet filmmaking practice. This film is not trying to raise consciousness or open our eyes to exploitation 
as such, but is a film that figures a concrete vision of the world. Rather than operating as a call-to-arms, as a propagandist piece or as a fetishised view of unity or utopia, Marker attends to what we could call the incompletion of what was lost or what never occurred. A Grin Without a Cat does not pose a solution to a problem, nor-more polemically-does it even suggest there is a problem that requires a solution. A Grin Without a Cat is not a simple reflection of the history of the 1968 movement, but tries to film that history as it is and in that process it is a film that tries to recognise its own incompletion in itself.

This visual paradox is an extension of cinéma vérité, direct cinema. Described in the words of one of its founding theorists, sociologist Edgar Morin, the aesthetic practice of this movement is to pose reality as though it can be seen, then to pose that reality as a question. Marker uses the idea of the grin without a cat to figure this paradox, and the montage becomes like the haunting gaze of the cat as an imagistic address to the spectator. In Marker, the cat is a living shadow, the cat who stares back without positive or negative judgment but in whose eyes we see a kind of truth of the world.

\section{Part II: I'm writing you this letter from a distant land}

I discussed these ideas with my 7-year-old cat, Copernicus. We both agree with Marker that cats have total knowledge and access to the truth itself, and Copernicus has responded with a letter to Marker.

\section{Dear Chris Marker,}

A Grin Without a Cat seeks an invisible cat, but in that seeking it is overwrought with a wistful longing for cats to appear from behind the smile.

You say that cats are not on the side of power, but I say that precisely because we renounce and reject everything we are absolutely on the side of power. On behalf of all cats, I reject your film.

Your film is not a grin without a cat, but wants to be a cat without a grin. It is obscured by the noise of the 1960s, and 
a sentimental, overwrought vision of its own importance. The deceptions have been taken too seriously, as if the fact that the film knows the problems of its present have been lost to the future is enough to confer to yourself, and to your viewers, the destination in sight. Recall Alice asking the Cheshire cat what direction she should take in order to reach her imagined destination:

“"Would you tell me, please, which way I ought to go from here?"

"That depends a good deal on where you want to get to," said the Cat.

"I don't much care where-" said Alice.

“Then it doesn't matter which way you go," said the Cat.

“- so long as I get somewhere," Alice added as an explanation.

"Oh, you're sure to do that," said the Cat, "if you only walk long enough."”

Chris Marker: your films operate as though the idea that you have not seen what you want to see can be seen through the filmic lens, and as though the eyes of your audience, your intended viewers for this imagined vision, cannot see and have never seen what has always been directly in front of them. For that reason, A Grin Without a Cat is an exploitation of their imagination and their visual sense.

Yours,

Copernicus 


\section{Notes}

1 Peter Aspden, 'Chris Marker: Phantom of Cinema', Financial Times, 28 March 2014.

2 For a full list of interviews see http://chrismarker.org/chris-marker/.

3 See, for example, Laura Mulvey, 'Looking at the Past Through the Present:

Rethinking Feminist Film Theory of the 1970s', Signs, vol. 30, no. 1, Autumn 2004, 1284-92. 